\title{
Effect of L-Arginine on the Serum Level of Advanced Glycation End Products in Patients with Post Infarction Chronic Heart Failure
}

\author{
Olexandr V. Kuryata ${ }^{1, *}$ and Abdunaser A. Zabida ${ }^{2}$
}

${ }^{1}$ State Establishment, Dnipropetrovsk Medical Academy, Ministry of Health, Ukraine

${ }^{2}$ Department of Internal Medicine \#2, Vernadskogo 9, Dnipro, 49005, Ukraine

\begin{abstract}
Post-infarction heart failure with preserved ejection fraction (HFpEF) determines a great morbidity and mortality, and given the physiopathology implications of advanced glycation end products (AGEs) in the genesis of myocardial dysfunction. As known endothelial dysfunction is an independent predictor for cardiovascular disease. LArginine is the amino acid with potential to improve endothelial function which leading to prevention and treatment of cardiovascular diseases, and we think that L-Arginine may decrease the serum AGEs. We aimed to estimate the value of AGEs in post-infarction HFpEF patients, and detect the effect of L-Arginine on the serum level of AGEs in postinfarction HFpEF pts. all individuals (25) included aged 40 to 80 years, $20(80 \%)$ males and $5(20 \%)$ females were diagnosed with (HFpEF) according to ESC guidelines (2012), and their functional class according to NYHA classification for HF. 20(80\%) patients of them have myocardial infarction in anamnesis. $1^{\text {st }}$ group:13 patients with HFpEF and history of myocardial infarction with L-Arginine added to their standard treatment. $2^{\text {nd }}$ group:7 patients with HFpEF and history of myocardial infarction with standard treatment (without L-Arginine). Comparsion group: 5 patients with HFpEF with standard treatment. We prescribed L. Arginine aspartate (Tivortin 4.2gm) intravenously once daily for 10 days for all $1^{\text {st }}$ group patients. The levels of total cholesterol, triglycerides, glucose, white blood cells, erythrocyte sedimentation rate and AGEs serum level were deterimined. AGEs serum level increased markedly increased in middle-age pts with post infarction HFpEF. Inclusion of L-arginine aspartate in complex of treatment for post infarction HFpEF contributed to the significant decrease AGEs level in $>60$ years old patients.
\end{abstract}

Keywords: Heart failure with preserved ejection fraction, advanced glycated end products, endothelialdys function, myocardialinfarction, L-Arginine.

\section{INTRODUCTION}

Chronic kidney disease (CKD) and cardiovascular disease (CVD) are strongly interlinked with each other, and they share common risk factors such as diabetes mellitus or hypertension [1]. In the context of CKD and $C V D$, the interest towards the post-translational modifications (PTMs) of proteins has grown considerably. Analysis of PTMs might be useful for the identification of mechanisms which play a role in the genesis and/or progression of CKD and CVD because proteins are constantly being exposed to different plasma and tissue components under different pathophysiological conditions.

PTMs are covalent changes of proteins or peptides that are altered either by proteolytic cleavage or by adding moieties to one or more amino acids. This enhances their complexity with respect to regulation of activity state, subcellular localization, turnover and interaction with other cellular molecules [2]. PTM proteins and peptides have gained attention as biomarkers and/or mediators of CVD and CKD [3, 4].

Already in the year 1912, a French chemist incubated proteins with aqueous glucose solution and

*Address correspondence to this author at the State Establishment, Dnipropetrovsk Medical Academy, Ministry of Health, Ukraine;

E-mail: gt1@dsma.dp.ua observed a yellow-brown pigment. He named this brown pigment 'Maillard pigment' and the underlying reaction as 'Maillard reaction' [5]. The free aldehyde of reducing sugar or sugar derivatives attacks amino group of proteins or amino acids to form a Schiff base which is slowly reversible. Furthermore, it rearranges to a more stable ketoamine called an 'Amadori product', i.e. fructosamine or fructosyl-lysine. 'Amadori products' can be exposed to irreversible oxidation, condensation, dehydration and degradation, resulting in the formation of highly stable products known as AGEs, which can form cross-links between proteins. Pentosidine, CML and $\mathrm{N}$-carboxyethyl-lysine (CEL) are few examples of glycoxidation products. Furthermore, AGEs are synthesized during carbonyl stress, found even in normoglycemic CKD patients. Reactive dicarbonyl compounds (a-oxoaldehyde) like glyoxal, methylglyoxal and 3-deoxyglucosone are formed by oxidation of sugar-derived metabolites such as glyceraldehyde-3phosphate and dihydroxyacetone-phosphate. These metabolites interact with lysine and arginine to form hydroimidazolone AGEs like glyoxal-hydroimidazolone1, methylglyoxal-hydroimidazolone-1 and argpyrimidine which are mostly found in plasma and tissues. In addition to carbohydrate intermediates, if lipid intermediates (malondialdehyde) are involved, the products are termed as 'advanced lipoxidation endproducts' (ALEs). In biological systems, glycated 
proteins undergo proteolysis to form low-molecularweight peptides or amino acids which are named as glycation free adducts that are sensitive to change in renal clearance [6]. The AGEs bind to their cell-bound receptors (RAGE), which is a multi-ligand receptor expressed on different cell types, and on activation generates ROS, activate NF-KB and MAPK signalling pathway thus contributing to inflammation and endothelial dysfunction leading to cardiovascular events [7]. Current studies show that these effects are observed only when aggregates of glycated proteins bind to RAGE, which is unlikely to exist in physiologic systems [8].

Glycation refers to a non-enzymatic reaction of reducing sugars with the amino group of amino acids, nucleic acids, lipids and proteins [9]. These targets of glycation processes undergo rearrangements to form stable heterogeneous compounds called AGEs. AGEs like pentosidine [10], $\mathrm{N}$-carboxymethyl-lysine (CML) are formed oxidatively (glycoxidation products), but methylglyoxal-derived hydroimidazolone MG-H1, the major AGE, is formed non-oxidatively.

Increased prevalence of heart failure (HF) is related to aging of the population and an improved survival after myocardial infarction [11]. The number of HF hospitalizations has also increased [12]. Advanced glycation endproducts (AGEs) increase during aging, and are suggested to be a pathophysiological mechanism for the increased prevalence of HF in the elderly population [13].

AGEs are end-products formed by oxidative and non-oxidative reactions between sugars and proteins [14]. AGEs form cross-links with long-living tissue proteins, which cause them to accumulate in the body over time. AGEs can bind to the receptor of AGE (RAGE) and thereby induce cardiovascular dysfunction [13]. RAGE has a C-truncated secretory isoform, soluble RAGE (sRAGE), that circulates in plasma [15]. SRAGE has been proposed to have an atheroscleroticprotective function [16, 17]. However, AGE-RAGE interaction can also cause inflammation and increased AGE-accumulation [18]. AGE-accumulation in turn can cause up regulation of RAGE [18]. Through decreased compliance of the heart and the vasculature, AGE accumulation is considered to be related to the onset and progression of HF [13].

In a smaller group of systolic HF patients, we recently showed that plasma AGE $N \varepsilon$ (carboxymethyl)lysine (CML) was related to prognosis
[19]. However, after adjustment for renal function, this relation subsided. In another study, serum pentosidine was related to severity of HF, although this was not adjusted for important potential confounders, such as haemoglobin and sex [20]. In addition, sRAGE had been associated with impaired outcome in a small cohort of HF patients [21].

Heart failure (HF) is a major cause of morbidity and mortality. Its incidence is increasing, in part as a secondary effect of the growing number of myocardial infarction survivor patients due to advances in drug therapy and cardiovascular interventions [22]. After myocardial infarction, physiological and anatomical ventricular changes occur. Left ventricular dilatation, eccentric hypertrophy, thinning of myocardial wall in the area of the scar and eventually left ventricular geometry alteration are aspects that define this process [23].

These changes are collectively known as ventricular remodelling, and they start a little after the myocardial infarction (even before any symptoms has been shown) as a progressive process that involves a worse prognosis for patients [24].

Ventricular remodelling is based on a neurohormonal model in which compensatory mechanisms of hormones and peptides acting in the kidney, as well as the peripheral vascular system and myocardium are implicated [25].

There is also an inflammatory reaction with release of cytokines, growth factors and reactive oxygen species production [26], which contributes to perpetuate ventricular dysfunction and could have important implications for prognosis.

AGE levels are increased in pro-inflammatory and oxidative stress states [26, 27]. Either by their direct interaction with proteins, such as extracellular collagen, or by its interaction with its receptor (RAGE), AGE can lead to diastolic, systolic and vascular dysfunction [28].

Therefore, it could be hypothesized that, instead of acting as a single marker, these glycation end products might play an important role in post-infarction HF [29].

Patients with CHF have endothelial dysfunction of systemic arteries which may be partially reversed by administration of oral Larginine_substrate for endothelial nitric oxide, NO. There is also evidence of abnormal NO responses in pulmonary arteries in a canine model of heart failure. Therefore, we 
hypothesised that abnormalities in pulmonary endothelial function in CHF patients might contribute to exercise perfusion ventilation mismatch and breathlessness and that these abnormalities might be improved by administration of intravenous L-arginine (L-arginine is also a vasodilator) [30].

In this work, we analyze the prognostic value of advanced (AGE) glycation products in the development of post-infarction HF, and detect the effect of L-Arginine on the serum level of AGEs in post-infarction $\mathrm{HF}$ patients.

\section{MATERIALS AND METHODS}

\section{Baseline Study}

The study was conducted with approval from the Ethics committee at sState Establishment Dnipropetrovsk Medical Academy, Ministry of Health Ukraine> according to principles outlined in the Helsinki declaration.

All individuals (25) included aged 40 to 80 years, 20 males and 5 females were diagnosed with preserved ejection fraction chronic heart failure (HFpEF), according to ESC guidelines (2012) [31], and their functional class according to NYHA classification for HF. 20 patients of them have myocardial infarction in anamnesis.

All patients got standard treatment for HFpEF according to ESC guidelines 2012 [31].

Patients with fresh acute myocardial infarction, $2^{\text {nd }}$ and $3^{\text {rd }}$ degree heart block, diabetes mellitus (DM) glycated haemoglobin $\geq 7$, acute, chronic renal and hepatic failure were excluded.

Standard laboratory blood tests for erythrocyte sedimentation rate, haematological parameters, lipid profile, glucose, renal and liver function tests were performed and calculated body mass index (BMI) for all patients.

The fluorescent(f) AGEs in plasma were analysed by quantitative autofluorescence (fluorimeter Hoefer DQ 2000, USA) with fixed spectrum of excitation at 460 $\mathrm{nm}$ with $20 \%$ quinine solution as a standard with results expressed with conversion to glycated albumin.

All analysis made for every patient 2 times, first time at the day of admission second analysis made at the $14^{\text {th }}$ day after starting treatment.

\section{Study Design}

We divided all included patients into two main groups and one control group.

$1^{\text {st }}$ group: 13 patients with HFpEF and history of myocardial infarction with L-Arginine added to their standard treatment.

$2^{\text {nd }}$ group: 7 patients with HFpEF and history of myocardial infarction with standard treatment (without L-Arginine).

$3^{\text {rd }}$ group: 5 patients with HFpEF with standard treatment.

We gave L. Arginine $(4.2 \mathrm{~g} / 100 \mathrm{ml})$ intravenously once daily for 7 days for all $1^{\text {st }}$ group patients.

Aim of our study to evaluate the effect of L-Arginine on the level of AGEs in patients with post infarction heart failure.

\section{RESULTS}

In Table 1, demographic, clinical and analytic characteristics of patients have been summarized.

Analyzed patients were not significantly different in blood glucose level, heart rate, WBCs, ESR and cholesterol. While more patients with triglyceridemia $(25 \%)$ in patients with history of MI.

Attention is drawn to the greater number of males in the group who underwent Ml compared with females. In all groups, the predominant risk factor was arterial hypertension with a more severe clinical course in patients with $\mathrm{MI}$ in anamnesis.

$84 \%$ of HFpEF pts were with $3^{\text {rd }}$ functional class (Fc) while $16 \%$ were with $2^{\text {nd }} \mathrm{Fc}$, after 2 to 4 weeks of admission all $3^{\text {rd }} \mathrm{Fc}$ converted to 2.6 and $2.5 \mathrm{Fc}$, after 6 weeks all pts were with 2nd Fc.

Median level of AGE in observed pts was 1.59 [1.38; 1.83$] \mathrm{mg} / \mathrm{ml}$, increased level was estimated in 21 (95.5\%) pts at baseline. The level of AGE was highly correlated in age $(R=0.68(p<0.05)$, IM anamnesis presence $(R=0.71(p<0.05) .>60$ years old patients with CHF characterized by significant higer AGEs level in compare with $40-59$ years old pts group $(p=0.02)$ at the baseline and after 2 weeks observation.

After 2 weeks of treatment with L-Arginine mean AGEs was decreased by $19 \%$ on the whole $(p<0.01)$, in 
Table 1: Baseline Characteristics of the Study Population

\begin{tabular}{|c|c|c|c|c|}
\hline \multicolumn{2}{|c|}{ Characterstics } & $\begin{array}{c}1^{\text {st }} \text { group } \\
\text { Post infarction CHF with } \\
\text { L.Arginine } \\
(n=13)\end{array}$ & $\begin{array}{l}\text { 2ndgroup } \\
\text { Post infarction CHF with } \\
\text { Standard treatment } \\
(n=7)\end{array}$ & $\begin{array}{c}\text { Comparsion group } \\
\text { CHF without MI } \\
\text { + standard treatment } \\
(n=5)\end{array}$ \\
\hline \multirow{2}{*}{ Gender } & Males $(\%)$ & $11.00(84.61 \%)$ & $5.00(71.42 \%)$ & $4.00(80.00 \%)$ \\
\hline & Females(\%) & $2.00(15.38 \%)$ & $2.00(28.57 \%)$ & $1.00(20.00 \%)$ \\
\hline \multicolumn{2}{|c|}{ Blood glucose $\mathrm{M} \pm \mathrm{m}$} & $5.65 \pm 0.85$ & $5.00 \pm 0.50$ & $5.00 \pm 0.40$ \\
\hline \multicolumn{2}{|c|}{ Heart rate (beat/minute) $M \pm m$} & $75.00 \pm 5.00$ & $76.00 \pm 4.00$ & $79.50 \pm 9.50$ \\
\hline \multicolumn{2}{|c|}{ Atrial fibrillation (\%) } & $2.00(15.38 \%)$ & $1.00(14.28 \%)$ & ---------- \\
\hline \multicolumn{2}{|c|}{ Arterial hypertension $\%$} & $12.00(92.30 \%)$ & $6.00(85.71 \%)$ & $3.00(60.00 \%)$ \\
\hline \multicolumn{2}{|c|}{ Cholesterol mmol/l ( $\mathrm{M} \pm \mathrm{m})$} & $5.49 \pm 2.31$ & $4.53 \pm 1.51$ & $5.60 \pm 1.90$ \\
\hline \multicolumn{2}{|c|}{ Triglycerides $\mathrm{mmol} / \mathrm{l} \mathrm{M} \pm \mathrm{m}$} & $2.13 \pm 1.43$ & $2.88 \pm 1.82$ & $1.20 \pm 0.07$ \\
\hline
\end{tabular}

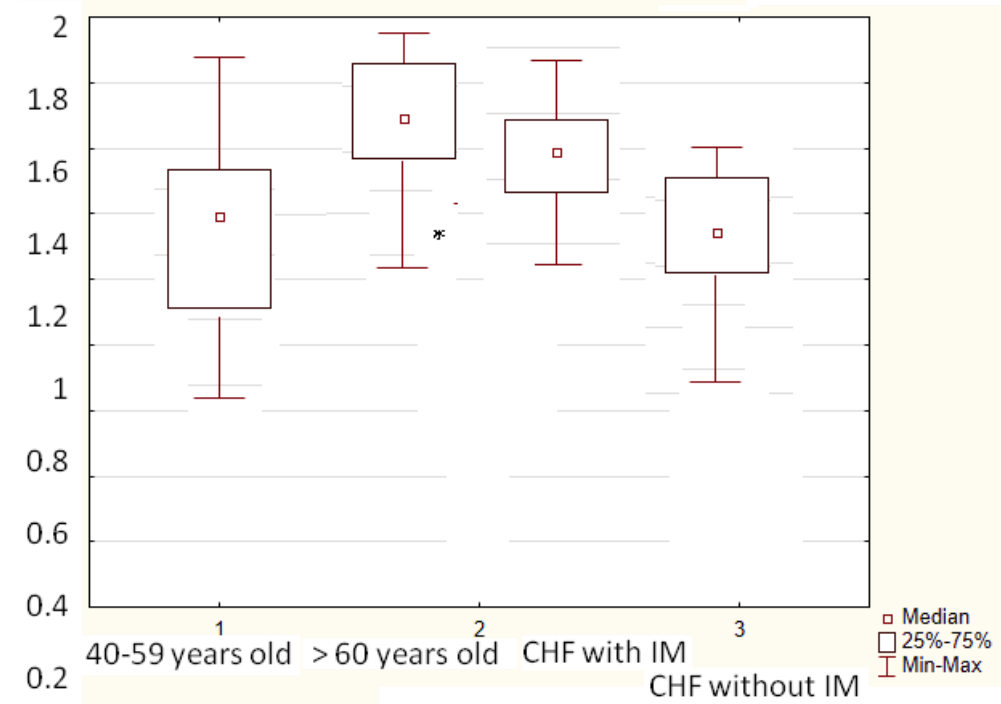

Figure 1: Median level of AGE in pts with CHF depending on age, IM presence in anamnesis at the baseline.

* - significant differences between the groups depending on age $p<0.05$ (by Mann-Whitney test).

compare with standard therapy - on 5\% ( $p=0.03)$. Table 2 shows after 2 weeks of L-Arginine supplementation the AGEs level was significantly less than in standart therapy group depending on age structure. Maximal dynamic of AGEs level decreasing was estimated in $>60$ years old patients $(\Delta=-23.3 \%)$ compare with $40-59$ years old pts $(\Delta=-1.4 \%), p<0.05$. The inclusion of L-arginine aspartate contributed to the significant decrease AGEs level compare with standart treatment in both age subgroups $(p<0.05)$. Should be noted no significant changes in the level of AGEs in patients without IM in anamnesis ( $p>0.05)$.

\section{DISCUSSION}

AGE promote endothelial dysfunction secondary to a reduced nitric oxide bioavailability mediated by free radicals [32] and they have shown to increase endothelial permeability in vitro [33].

Endothelial dysfunction is involved in the early stages of atherosclerosis and may trigger endothelium repair by endothelial progenitor cells. However, AGE have demonstrated to promote apoptosis and impair functions of endothelial progenitor cells in culture [34] 


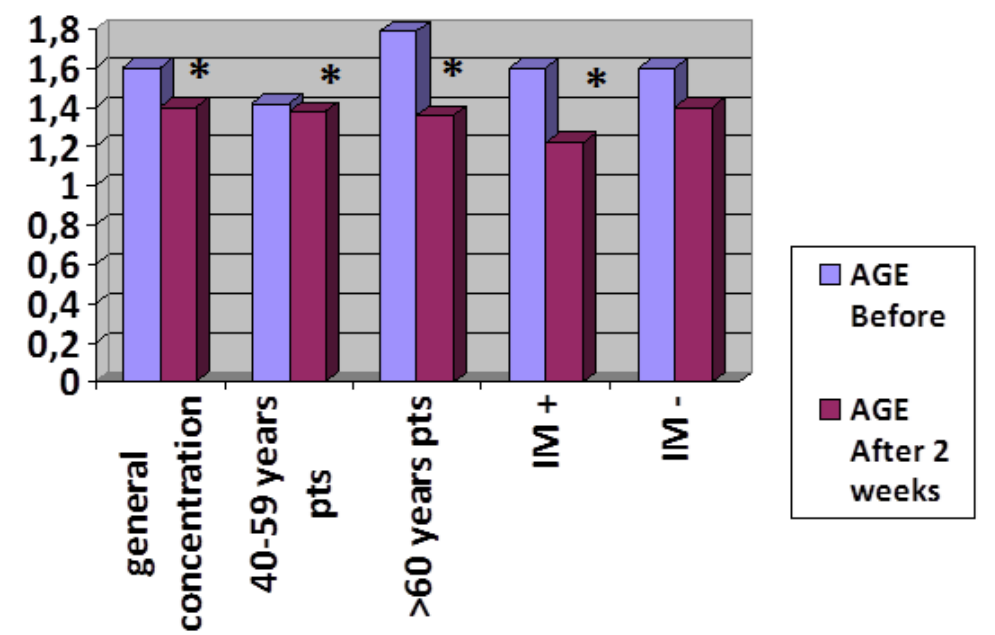

Figure 2: Median level of AGE in pts with CHF at the baseline and after 2 weeks and depending on age, IM anamnesis presence.

* significant differences between groups in dynamics $p<0.05$ (by Wilcoxon test).

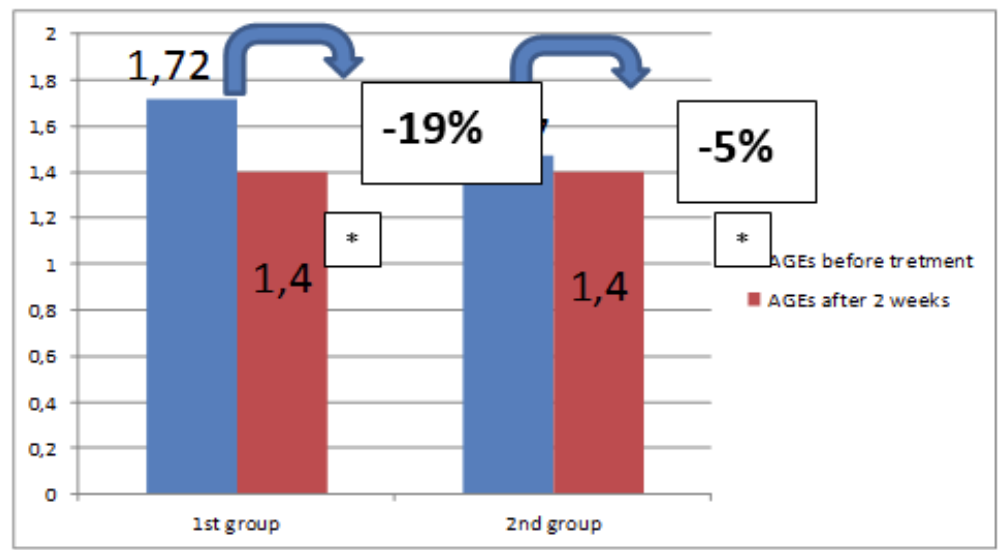

Figure 3: Dynamic of AGEs level depending on L-Arginine administration in pts with CHF with IM anamnesis presence.

Table 2: AGEs Level Dynamic in Observed Groups Depending on Age

\begin{tabular}{|c|c|c|c|c|c|c|}
\hline & \multicolumn{2}{|c|}{$\begin{array}{c}1^{\text {st }} \text { group } \\
\text { (+L-Arginine) }\end{array}$} & \multicolumn{2}{|c|}{$\begin{array}{c}2^{\text {nd }} \text { group } \\
\text { (-L-Arginine) }\end{array}$} & \multicolumn{2}{|c|}{ Pts without IM } \\
\hline & $\begin{array}{c}\text { AGEs } \\
\text { baseline }\end{array}$ & $\begin{array}{c}\text { AGEs } \\
\text { After } \\
2 \text { weeks }\end{array}$ & $\begin{array}{c}\text { AGEs } \\
\text { baseline }\end{array}$ & $\begin{array}{c}\text { AGEs } \\
\text { After } \\
2 \text { weeks }\end{array}$ & $\begin{array}{c}\text { AGEs } \\
\text { baseline }\end{array}$ & $\begin{array}{c}\text { AGEs } \\
\text { After } \\
2 \text { weeks }\end{array}$ \\
\hline 40-59 years old & $\begin{array}{c}1.48 \\
{[1.26 ; 1.78]}\end{array}$ & $\begin{array}{c}1.46 \\
{[1.32 ; 1.77]}\end{array}$ & $\begin{array}{c}1.37 \\
{[1.16 ; 1.69] \#}\end{array}$ & $\begin{array}{c}1.34 \\
{[1.14 ; 1.61] \#}\end{array}$ & $\begin{array}{c}1.53 \\
{[1.27 ; 1.56]}\end{array}$ & $\begin{array}{c}1.48 \\
{[1.34 ; 1.53]}\end{array}$ \\
\hline
\end{tabular}

*significant differences between groups in dynamics $p<0.05$ (by Wilcoxon test).

\#- significant differences between the groups depending on age $p<0.05$ (by Mann-Whitney test).

and also to reduce growth and migration of mesenchymal stem cells [35].

The AGE-RAGE axis accelerates post-infarct myocardium remodelling, generating a deleterious feedback mechanism.
In fact, the relation between the rennin-angiotensin aldosterone system, a relevant system in ventricular remodelling and with demonstrated pathophysiological implications, with AGE-RAGE axis has been suggested [36]. So, angiotensin converting enzyme inhibitors and angiotensin II receptor antagonists reduced plasma 
AGE levels [37]. In contrast, it has been demonstrated that AGE promote angiotensin II formation [38].

Alagebrium, an AGEbreaker, has not shown to improve physical exercise tolerance land other secondary endpoints in patients with heart failure in the BENEFICIAL clinical trial [39]. Even though, it is clear that AGE can play a role in post-infarction HF, being crucial elements of ventricular remodelling.

The higher level of AGE found in patients with postinfarction HF showed the pathophysiological role that these molecules can play in ventricular remodelling.

This means that, rather than a simple risk biomarker after an acute myocardial infarction, AGE can be a new etiological way to focus therapeutic research to reduce the harmful effects of remodelling.

There are some blockers of the AGE-RAGE axis that have been studied in animals. The best known are aminoguanidine, an AGE formation inhibitor [40], and alagebrium (ALT-711), an AGE breaker [41]. Both molecules have been tested in animals showing an improvement of myocardial compliance [40] and an enhancement of cardiac function in animals with contractile dysfunction [41]. The effect of alagebrium on diastolic dysfunction has also been studied in humans $[41,42]$.

In the DIAMOND trial 23 stable patients with diastolic dysfunction were treated with alagebrium. After 16 weeks, left ventricle mass was reduced and diastolic function was improved [42]. The PEDESTAL trial studied the effects of alagebrium in HF patients with depressed systolic function (LVEF < 45\%) and the preliminary results showed a tendency to improve systolic function [43].

It is clear that L-Arginine have anti-inflammatory effect, improving endothelial function and to some extent decrease the level of AGEs in patients with post infarction $\mathrm{HF}$, but still not clear if L-Arginine superior to AGE formation inhibitors, AGE-RAGE blockers and AGE breakers, so this need more study.

\section{LIMITATIONS}

Despite stupendous results, we are aware of the limitations of our study mainly because of few number of patients and less females included, short control time (just 6 weeks) which not enough for adequate evaluation of hard end point and finally, AGEs were measured by Much's method, which means that an unspecified mixture of different fluorescent AGE were detected in the measurement, but non-fluorescent AGEs were not considered.

\section{CONCLUSIONS}

1. AGEs serum level markedly increased in middleage (40-59 y.o) pts with post infarction HFpEF.

2. Inclusion of L-arginine aspartate in complex of treatment for post infarction HFpEF contributed to the significant decrease AGEs level in $>60$ years old patients.

\section{REFERENCES}

[1] Sarnak MJ. Cardiovascular complications in chronic kidney disease. Am J Kidney Dis 2003; 41(5 Suppl): 11-17. https://doi.org/10.1016/S0272-6386(03)00372-X

[2] Mann M, Jensen ON. Proteomic analysis of post-translational modifications. Nat Biotechnol 2003; 21: 255-261. https://doi.org/10.1038/nbt0303-255

[3] Gillery $P$, Jaisson $S$. Usefulness of non-enzymatic posttranslational modification derived products (PTMDPs) as biomarkers of chronic diseases. J Proteomics 2013; 92: 228238.

https://doi.org/10.1016/j.jprot.2013.02.015

[4] Gillery P, Jaisson S. Post-translational modification derived products (PTMDPs): toxins in chronic diseases? Clin Chem Lab Med 2014; 52: 33-38. https://doi.org/10.1515/cclm-2012-0880

[5] Maillard L-C. Action des acides amines sur les sucres: formation des melanoidines par voie methodique. C R Seances Acad Sci III 1912; 154: 66-68.

[6] Rabbani N, Sebekova K, Sebekova K Jr., et al. Accumulation of free adduct glycation, oxidation, and nitration products follows acute loss of renal function. Kidney Int 2007; 72 1113-1121.

https://doi.org/10.1038/sj.ki.5002513

[7] Sadik NA, Mohamed WA, Ahmed MI. The association of receptor of advanced glycated end products and inflammatory mediators contributes to endothelial dysfunction in a prospective study of acute kidney injury patients with sepsis. Mol Cell Biochem 2012; 359: 73-81. https://doi.org/10.1007/s11010-011-1001-4

[8] Tarng DC, Huang TP, Wei YH, et al. 8-hydroxy-20deoxyguanosine of leukocyte DNA as a marker of oxidative stress in chronic hemodialysis patients. Am J Kidney Dis 2000; 36: 934-944. https://doi.org/10.1053/ajkd.2000.19086

[9] Simm A. Protein glycation during aging and in cardiovascular disease. J Proteomics 2013; 92: 248-259. https://doi.org/10.1016/j.jprot.2013.05.012

[10] Sell DR, Monnier VM. End-stage renal disease and diabetes catalyze the formation of a pentose-derived crosslink from aging human collagen. J Clin Invest 1990; 85: 380-384. https://doi.org/10.1172/JCl114449

[11] Smit AJ, Hartog JW, Voors AA, et al. Advanced glycation endproducts in chronic heart failure. Ann N Y Acad Sci 2008; 1126: $225-30$.

https://doi.org/10.1196/annals.1433.038

[12] Dunlay SM, Redfield MM, Weston SA, et al. Hospitalizations after heart failure diagnosis a community perspective. J Am Coll Cardiol 2009; 54: 1695-702. https://doi.org/10.1016/j.jacc.2009.08.019 
[13] Hartog JW, Voors AA, Bakker SJ, et al. Advanced glycation endproducts (AGEs) and heart failure: pathophysiology and clinical implications. Eur J Heart Fail 2007; 9: 1146-55. https://doi.org/10.1016/j.ejheart.2007.09.009

[14] Miyata T, Sugiyama S, Saito A, et al. Reactive carbonyl compounds related uremic toxicity ("carbonyl stress"). Kidney Int Suppl 2001; 78: S25-31.

https://doi.org/10.1046/j.1523-1755.2001.59780025.x

[15] Raposeiras-Roubín S, Rodiño-Janeiro BK, GrigorianShamagian L, et al. Soluble receptor of advanced glycation end products levels are related to ischaemic aetiology and extent of coronary disease in chronic heart failure patients, independent of advanced glycation end products levels: new roles for soluble RAGE. Eur J Heart Fail 2010; 12: 1092-100. https://doi.org/10.1093/eurihf/hfq117

[16] Lindsey JB, de Lemos JA, Cipollone F, et al. Association between circulating soluble receptor for advanced glycation end products and atherosclerosis: observations from the Dallas Heart Study. Diabetes Care 2009; 32: 1218-20. https://doi.org/10.2337/dc09-0053

[17] Falcone C, Emanuele E, D'Angelo A, et al. Plasma levels of soluble receptor for advanced glycation end products and coronary artery disease in nondiabetic men. Arterioscler Thromb Vasc Biol 2005; 25: 1032-7. https://doi.org/10.1161/01.ATV.0000160342.20342.00

[18] Ramasamy R, Yan SF, Schmidt AM. Advanced glycation endproducts: from precursors to RAGE: round and round we go. Amino Acids 2010: 19.

[19] Hartog JW, Voors AA, Schalkwijk CG, et al. Clinical and prognostic value of advanced glycation end-products in chronic heart failure. Eur Heart J 2007; 28: 2879-85. https://doi.org/10.1093/eurheartj/ehm486

[20] Koyama $Y$, Takeishi $Y$, Arimoto $T$, et al. High serum level of pentosidine, an advanced glycation end product (AGE), is a risk factor of patients with heart failure. J Card Fail 2007; 13: 199-206. https://doi.org/10.1016/j.cardfail.2006.11.009

[21] Raposeiras-Roubín S, Rodiño-Janeiro BK, GrigorianShamagian L, et al. Relation of soluble receptor for advanced glycation end products to predict mortality in patients with chronic heart failure independently of Seattle Heart Failure Score. Am J Cardiol 2010; 107: 938-44.

https://doi.org/10.1016/j.amjcard.2010.11.011

[22] Macchia A, Levantesi G, Marfisi RM, Franzosi MG, Maggioni AP, Nicolosi GL, Schweiger C, Tavazzi L, Tognoni G, Valagussa $F$, et al. Determinants of lateonset heart failure in myocardial infarction survivors: GISSI Prevenzione trial results. Rev Esp Cardiol 2005; 58(11): 1266-1272.

https://doi.org/10.1157/13080953

[23] Gajarsa JJ, Kloner RA. Left ventricular remodeling in the post-infarction heart: a review of cellular, molecular mechanisms, and therapeutic modalities. Heart Fail Rev 2011; 16(1): 13-21.

https://doi.org/10.1007/s10741-010-9181-7

[24] Cohn JN, Ferrari R, Sharpe N. Cardiac remodeling-concepts and clinical implications: a consensus paper from an international forum on cardiac remodeling. Behalf of an International Forum on Cardiac Remodeling. J Am Coll Cardiol 2000; 35(3): 569-582.

https://doi.org/10.1016/S0735-1097(99)00630-0

[25] Roig Minguell E. Clinical use of markers of neurohormonal activation in heart failure. Rev Esp Cardiol 2004; 57(4): 347356. https://doi.org/10.1016/S0300-8932(04)77113-4

[26] Dominguez Rodriguez A, Abreu Gonzalez P, Garcia Gonzalez MJ, Ferrer Hita J. Association between serum interleukin 10 level and development of heart failure in acute myocardial infarction patients treated by primary angioplasty. Rev Esp Cardiol 2005; 58(6): 626-630.

https://doi.org/10.1016/s1885-5857(06)60248-x
Basta G, Lazzerini G, Massaro M, Simoncini T, Tanganelli $P$, Fu C, Kislinger T, Stern DM, Schmidt AM, De Caterina R. Advanced glycation end products activate endothelium through signal-transduction receptor RAGE: a mechanism for amplification of inflammatory responses. Circulation 2002; 105(7): 816-822.

https://doi.org/10.1161/hc0702.104183

[28] Giacco F, Brownlee M. Oxidative stress and diabetic complications. Circ Res 2010; 107(9): 1058-1070. https://doi.org/10.1161/CIRCRESAHA.110.223545

[29] Hartog JW, Voors AA, Bakker SJ, Smit AJ, van Veldhuisen DJ. Advanced glycation end-products (AGEs) and heart failure: pathophysiology and clinical implications. Eur J Heart Fail 2007; 9(12): 1146-1155. https://doi.org/10.1016/j.ejheart.2007.09.009

[30] Kioifman B, Wollam Y, Bogomolny N, et al. Improved cardiac performance by intravenous infusion of L-arginine in patients with moderate congestive cardiac failure. J Am Coll Cardiol 1995; 26: 1251-1256. https://doi.org/10.1016/0735-1097(95)00318-5

[31] ESC Guidelines for the diagnosis and treatment The Task Force for the Diagnosis and Treatment of Acute and Chronic Heart Failure 2012 of the European Society of Cardiology. Developed in collaboration with the Heart Failure Association (HFA) of the ESC, European Heart Journal.

https://doi.org/10.1093/eurheartj/ehs104

[32] Soro-Paavonen A, Zhang WZ, Venardos K, Coughlan MT, Harris E, Tong DC, et al. Advanced glycation end-products induce vascular dysfunction via resistance to nitric oxide and suppression of endothelial nitric oxide synthase. J Hypertens 2010, 28(4): 780-788. https://doi.org/10.1097/HJH.0b013e328335043e

[33] Wang J, Liu H, Chen B, Li Q, Huang X, Wang L, Guo X, Huang $Q$. RhoA/ ROCK-dependent moesin phosphorylation regulates AGE-induced endothelial cellular response. Cardiovasc Diabetol 2012; 11: 7.

https://doi.org/10.1186/1475-2840-11-7

[34] Li H, Zhang X, Guan X, Cui X, Wang Y, Chu H, Cheng M. Advanced glycation end products impair the migration, adhesion and secretion potentials of late endothelial progenitor cells. Cardiovasc Diabetol 2012; 11(1): 46. https://doi.org/10.1186/1475-2840-11-46

[35] Yang K, Wang XQ, He YS, Lu L, Chen QJ, Liu J, Shen WF. Advanced glycation end products induce chemokine/cytokine production via activation of p38 pathway and inhibit proliferation and migration of bone marrow mesenchymal stem cells. Cardiovasc Diabetol 2010; 9: 66. https://doi.org/10.1186/1475-2840-9-66

[36] Kamioka M, Ishibashi T, Sugimoto K, Uekita H, Nagai R, Sakamoto $\mathrm{N}$, et al. Blockade of renin-angiotensin system attenuates advanced glycation end products-mediated signalling pathways. J Atheroscler Thromb 2010; 17(6): 590600.

https://doi.org/10.5551/jat.3624

[37] Yamagishi S, Matsui T, Nakamura K, Inoue H, Takeuchi M, Ueda S, Fukami K, Okuda S, Imaizumi T. Olmesartan blocks advanced glycation end products (AGEs)-induced angiogenesis in vitro by suppressing receptor for AGEs (RAGE) expression. Microvasc Res 2008; 75(1): 130-134. https://doi.org/10.1016/j.mvr.2007.05.001

[38] Koka V, Wang W, Huang XR, Kim-Mitsuyama S, Truong LD, Lan HY. Advanced glycation end products activate a chymase-dependent angiotensin II-generating pathway in diabetic complications. Circulation 2006; 113(10): 13531360.

https://doi.org/10.1161/CIRCULATIONAHA.105.575589

[39] Hartog JW, Willemsen S, van Veldhuisen DJ, Posma JL, van Wijk LM, Hummel YM, Hillege HL, Voors AA. Effects of alagebrium, an advanced glycation endproduct breaker, on 
exercise tolerance and cardiac function in patients with chronic heart failure. Eur J Heart Fail 2011; 13(8): 899-908. https://doi.org/10.1093/eurihf/hfr067

[40] Norton GR, Candy G, Woodiwiss AJ. Aminoguanidine prevents the decreased myocardial compliance produced by streptozotocin-induced diabetes mellitus in rats. Circulation 1996; 93(10): 1905-1912.

https://doi.org/10.1161/01.CIR.93.10.1905

[41] Liu J, Masurekar MR, Vatner DE, Jyothirmayi GN, Regan TJ, Vatner SF, Meggs LG, Malhotra A. Glycation end-product cross-link breaker reduces collagen and improves cardiac function in aging diabetic heart. Am J Physiol Heart Circ Physiol 2003; 285(6): H2587-2591.

https://doi.org/10.1152/ajpheart.00516.2003
[42] Little WC, Zile MR, Kitzman DW, Hundley WG, O'Brien TX, Degroof RC. The effect of alagebrium chloride (ALT-711), a novel glucose cross-link breaker, in the treatment of elderly patients with diastolic heart failure. J Card Fail 2005; 11(3): 191-195.

https://doi.org/10.1016/j.cardfail.2004.09.010

[43] Thohan V, Koemer MM, Pratt CM, Torre GA. Improvements in diastolic function amond patients with advenced systolic heart failure utilizing alagebrium (an oral advanced glycation end-product cross-link breaker). Circulation 2005; 112(Suppl 2): U620. 2647. 